\title{
Fertilizer Prescriptions under STCR-IPNS for Rice-Rice Cropping Sequence on An Inceptisol (Typic Ustropept)
}

\author{
U. Bagavathi Ammal*, K. Coumaravel, R. Sankar and Pradip Dey ${ }^{1}$ \\ Department of Soil Science and Agricultural Chemistry, \\ Pandit Jawaharlal Nehru College of Agriculture and Research Institute, Karaikal-609 603, Puducherry, India. \\ Received: 20-02-2019 \\ Accepted: 23-09-2019 \\ DOI: $10.18805 /$ IJARe.A-5228
}

\begin{abstract}
To develop fertilizer prescription equations based on soil test crop response (STCR) approach for rice-rice cropping sequence, trials were conducted at farmer's field in Karikalampakkam village, U.T. of Puducherry, during 2015-16. Soil test data, yield and nutrient uptake by successive crops were recorded to calculate four basic parameters viz. nutrient required to produce one quintal of rice, contribution of nutrients from fertilizers, contribution of nutrients from soil and contribution of nutrients from FYM used in developing STCR based fertilizer prescription equations. The per cent nutrient contribution of nutrients from soil (CS), fertilizer (CF) and FYM (CFYM) were found to be 19.15, 45.90 and 23.27 for N, $12.13,40.16$ and 26.98 for $\mathrm{P}_{2} \mathrm{O}_{5}$ and $13.76,79.64$ and 41.07 for $\mathrm{K}_{2} \mathrm{O}$ respectively for rice cv. White ponni. The same for the rice cv.ADT 45 were 13.48, 40.46 and 34.26 for $\mathrm{N}, 15.81,44.64$ and 19.89 for $\mathrm{P}_{2} \mathrm{O}_{5}$ and $10.48,58.64$ and 41.51 for $\mathrm{K}_{2} \mathrm{O}$ respectively. Based on fertilizer prescription equations and nomograms formulated for a range of soil test values and desired yield target for the cropping sequence. It was revealed that under the treatment NPK + FYM @ $12.5 \mathrm{t} \mathrm{ha}^{-1}, 47,29$ and $34 \mathrm{~kg} \mathrm{ha}^{-1}$ for rice cv. White ponni and 41, 22 and $27 \mathrm{~kg} \mathrm{ha}^{-1}$ for rice cv.ADT 45 of fertilizer $\mathrm{N}_{2} \mathrm{P}_{2} \mathrm{O}_{5}$ and $\mathrm{K}_{2} \mathrm{O}$, respectively could be saved for attaining target yield of $70 \mathrm{q} \mathrm{ha}^{-1}$ compared to NPK fertilizers alone.
\end{abstract}

Key words: Fertilizer prescription equations, Rice-rice cropping sequence, STCR, Targetted yield.

\section{INTRODUCTION}

The conservative estimates show that the demand for food grains would increase from 257 million tons in 201213 to 355 million tons by 2030 (Dey, 2016). This increase in demand has to be met from the fixed arable land available ( 414 million ha), with less scope for further horizontal expansion out of which 120 million hectare is estimated to be suffering from different forms of land degradation (ICAR and NAAS, 2010).Contrary to increasing food demand, the factor productivity and rate of response of crops to applied fertilizers under intensive cropping are declining year after year. Although food grain production has increased many folds, the irony is that it has been achieved at the cost of deterioration of natural resources (Prasad, 2004). In India, the nutrient application rate has increased by $173 \%$, but average increase in total food grain was only $125 \%$ during the past five decades and at many places productivity got plateaued or showing decreasing trend.

Rice (Oryza sativa L.) is central to the lives of billions of people around the world. At the global level, rice is the most widely grown crop which occupies an area of about 161.8 million hectares, of which Asia covers about 143.2 million hectares. Similarly, out of the total world rice production of 701 million tons, Asia contributes approximately 633.7 million tons. The slogan 'Rice is life' is most appropriate for India as this crop plays a vital role in our food security and is a mean of livelihood for millions of rural households (Ajaykumar et al., 2016). In India, more than 44 million hectares of land is occupied by rice under three major ecosystems, rainfed uplands (16\%), irrigated medium lands (45\%) and rainfed lowland (39\%), with a productivity of $0.87,2.24$ and 1.55 tons $\mathrm{ha}^{-1}$, respectively (Tiwari et al., 2013). Although the largest area under rice crop in the world $\left(44 \mathrm{~m} \mathrm{ha}^{-1}\right)$ is in India, average productivity is lesser than that of China and Japan.

The annual consumption of fertilizers $\left(\mathrm{N}, \mathrm{P}_{2} \mathrm{O}_{5}\right.$ and $\left.\mathrm{K}_{2} \mathrm{O}\right)$ has increased from 0.07 million tons in $1951-52$ to more than 28 million tons in 2010-11 and per hectare consumption has increased from less than $1.0 \mathrm{~kg}$ in 1951-52 to the level of $135.0 \mathrm{~kg}$ in 2010-11 (Karsangla and Gohain, 2015), the nutrient use efficiency has gone down from $16 \mathrm{~kg}$ food grain produced per kg NPK applied during 1970's to 8 $\mathrm{kg}$ food grain produced per kg NPK applied during 1990's and around $6 \mathrm{~kg}$ now due to increasing deficiency of secondary and micronutrient (Tiwari et al., 2013).

The current fertilization practices do not put back in equal measure the nutrient to the soil as have been removed by crops, resulting in continuous depletion of soil fertility. This can be offset only by adopting soil testing and applying integrated plant nutrient supply (IPNS) as has been

*Corresponding author's e-mail: pancham112@gmail.com

${ }^{1}$ Project Coordinator, Indian Institute of Soil Science, Bhopal-462 038, Madhya Pradesh, India. 
enunciated as "The Law of Optimum", which has been demonstrated and validated in numerous farmer's field for obtaining targeted yield of crops under the All India Coordinated Research Project on Soil Test Crop Response (AICRP-STCR) project annual reports (Ramamoorthy and Velayutham, 2011, Tandan 2014 and Velayutham et al., 2016). The targeted yield approach where in Ramamoorthy et al. (1967) established the theoretical basis and experimental proof for the fact that Liebig's law of minimum operates equally well for N, P and K. In Union Territory of Puducherry, this type of work has not yet been initiated. Hence, the present work was carried out to develop STCR relationship for prescribing fertilizer recommendations under IPNS for desired yield targets for rice-rice cropping sequence on an Inceptisol of Puducherry.

\section{MATERIALS AND METHODS}

The experiments were conducted at farmer's field of Karikalampakkam village in Nettapakkam commune of U.T.of Puducherry. The study area comes under coastal alluvial plain classified as fine, mixed isohyperthermic, Typic Ustropept with an area of $12.72 \%$. According to agro climatic zonal classification, Puducherry is located at $11^{\circ} 56^{\prime}$ North latitude and $79^{\circ} 66^{\prime}$ East longitude. The soils of experimental field was slightly alkaline ( $\mathrm{pH}-8.4)$, non-saline in reaction and sandy clay loam in texture. The $\mathrm{P}$ and $\mathrm{K}$ fixing capacities of the soil were 15 and $100 \mathrm{~kg} \mathrm{ha}^{-1}$, respectively. The fertility status was low, high and medium with respect to available $\mathrm{N}$ (170.8 $\left.\mathrm{kg} \mathrm{ha}^{-1}\right), \mathrm{P}\left(65.4 \mathrm{~kg} \mathrm{ha}^{-1}\right)$ and $\mathrm{K}\left(236.0 \mathrm{~kg} \mathrm{ha}^{-1}\right)$. Following the inductive methodology of Ramamoorthy et al. (1967), the experiment was conducted in two phases. In the first phase, fertility gradient experiment was conducted by raising rice cv. kulla ponni as an exhaust crop during 2015 . For this, the field was divided into three equal which were fertilized with $\mathrm{N}_{0} \mathrm{P}_{0} \mathrm{~K}_{0}$ (strip-I), $\mathrm{N}_{1} \mathrm{P}_{1} \mathrm{~K}_{1}$ (strip-II) and $\mathrm{N}_{2} \mathrm{P}_{2} \mathrm{~K}_{2}$ (strip-1II) levels to create fertility gradient. Subsequently, in the second phase, after the harvest of the exhaust crop, rice cv. White ponni was transplanted as test crop on $9^{\text {th }}$ of November, 2015 and harvested on $11^{\text {th }}$ of March, 2016. After the harvest of rice cv. White ponni, rice cv. ADT 45 was transplanted on $1^{\text {st }}$ April, 2016 and harvested on $22^{\text {nd }}$ of June, 2016. Each of the fertility strips was subdivided into 24 sub- plots resulting in 72 plots. There were 24 treatments consists of four levels of $\mathrm{N}\left(0,50,100\right.$ and $\left.150 \mathrm{~kg} \mathrm{ha}^{-1}\right), \mathrm{P}_{2} \mathrm{O}_{5}(0,25$, 50 and $\left.75 \mathrm{~kg} \mathrm{ha}^{-1}\right), \mathrm{K}_{2} \mathrm{O}\left(0,25,50\right.$ and $\left.75 \mathrm{~kg} \mathrm{ha}^{-1}\right)$ and FYM (0.6.25 and $\left.12.5 \mathrm{tha}^{-1}\right)$. The moisture and $\mathrm{N}, \mathrm{P}_{2} \mathrm{O}_{5}$ and $\mathrm{K}_{2} \mathrm{O}$ contents of FYM were 28, 0.52, 0.32 and $0.38 \%$, respectively. Pre-sowing soil samples were collected from each plot for each crop and analysed for available N (alkaline permanganate method-Subbiah and Asija, 1956), available $\mathrm{P}$ (extraction with $0.5 \mathrm{M} \mathrm{NaHCO}_{3}-$ Olsen et al., 1954) and available K (ammonium acetate method - Stanford and English, 1949). Grain and straw yields of both rice crops were recorded and these samples were analysed for $\mathrm{N}$ (Humphries, 1956), P and K contents (Jackson, 1973) and uptake values were computed. Using the data on crop yield, nutrient uptake, pre-sowing soil available nutrient status and fertilizer doses applied, the basic parameters used in developing STCR based fertilizer prescription equation viz. nutrient (NR), contribution of nutrients from soil (CS), fertilizer (CF) and FYM (CFYM) were calculated as per procedure described by Ramamoorthy et al.(1967) and Santhi et al.(2002). Fertilizer doses and the soil test based fertilizer recommendations were formulated in the form of a ready reckoner for desired yield target of rice-rice under NPK alone as well as NPK+FYM.

\section{RESULTS AND DISCUSSION}

Soil available nutrients: Strip-wise range and mean soil test values of pre-sowing stage for available nutrients are given in Table 1. The average levels of available nutrients were found to increase with increasing fertility strips and the highest content was recorded in strip III. The average available $\mathrm{N}$ content increased from 150.6 to $228.7 \mathrm{~kg} \mathrm{ha}^{-1}$ and 151.6 to $211.2 \mathrm{~kg} \mathrm{ha}^{-1}$ for rice $\mathrm{cv} \mathrm{cv}$. White ponni and ADT 45, respectively. The increase in $\mathrm{N}$ could be due to the addition of double dose of NPK fertilizers than the single dose and control. The increased availability of $\mathrm{P}$ and $\mathrm{K}$ may be due to the application of graded levels of phosphatic and potassic fertilizers either at par with or over and above the $P$ and $\mathrm{K}$ fixing capacity of the experimental field. Similar buildup of P and K was noticed by Coumaravel (2012) and Bagavathi Ammal et al. (2013).

Table 1: Pre-sowing soil available NPK $\left(\mathrm{kg} \mathrm{ha}^{-1}\right)$ in various strips.

\begin{tabular}{|c|c|c|c|c|c|c|}
\hline \multirow[b]{2}{*}{ Strip } & \multicolumn{2}{|c|}{ Available N } & \multicolumn{2}{|c|}{ Available $\mathrm{P}_{2} \mathrm{O}_{5}$} & \multicolumn{2}{|c|}{ Available $\mathrm{K}_{2} \mathrm{O}$} \\
\hline & Range & Mean & Range & Mean & Range & Mean \\
\hline \multicolumn{7}{|c|}{ Rice cv. White ponni } \\
\hline Strip-I & $142.8-156.8$ & 150.6 & $42.2-49.8$ & 46.2 & $200-212$ & 208 \\
\hline Strip-II & $198.8-220.2$ & 205.8 & $50.4-59.6$ & 54.7 & $216-242$ & 229 \\
\hline Strip-III & $218.6-235.2$ & 228.7 & $51.6-61.9$ & 56.2 & $260-283$ & 270 \\
\hline \multicolumn{7}{|c|}{ Rice cv. ADT 45} \\
\hline Strip-I & $120.4-170.8$ & 151.6 & $37.3-55.8$ & 45.4 & $182-210$ & 203.4 \\
\hline Strip-II & $165.2-221.2$ & 205.3 & $42.9-59.2$ & 51.3 & $205-240$ & 226.9 \\
\hline Strip-III & $170.8-243.8$ & 211.2 & $47.4-61.3$ & 53.6 & $232-286$ & 263.8 \\
\hline
\end{tabular}


Table 2: Grain Yield and Nutrient uptake by rice-rice sequence $\left(\mathrm{kg} \mathrm{ha}^{-1}\right)$ in various strips.

\begin{tabular}{lcccccr}
\hline & \multicolumn{2}{c}{ Strip I } & \multicolumn{2}{c}{ Strip II } & \multicolumn{2}{c}{ Strip III } \\
\cline { 2 - 7 } Parameters & Range & Mean & Range & Mean & Range & Mean \\
\hline Rice cv.White ponni & $2860-7210$ & 5383 & $3015-7735$ & 5580 & $3360-8100$ & 5693 \\
Grain yield & $36.1-89.6$ & 73.1 & $38.0-104.2$ & 80.5 & $42.5-115.2$ & 86.2 \\
$\mathrm{~N}$ uptake & $6.0-17.9$ & 12.6 & $6.6-20.6$ & 15.2 & $7.7-21.6$ & 15.2 \\
$\mathrm{P}_{2} \mathrm{O}_{5}$ uptake & $28.9-75.2$ & 58.7 & $31.1-79.1$ & 63.9 & $36.2-85.1$ & 66.8 \\
$\mathrm{~K}_{2} \mathrm{O}$ uptake & & & & & & \\
Rice cv.ADT 45 & $2640-6400$ & 4954 & $2710-6580$ & 5177 & $2810-7110$ & 5405 \\
Grain yield & $19.4-82.6$ & 54.9 & $22.4-83.6$ & 65.2 & $24.8-101.2$ & 72.7 \\
$\mathrm{~N}$ uptake & $6.5-18.9$ & 14.6 & $6.9-24.8$ & 16.8 & $7.3-24.7$ & 17.7 \\
$\mathrm{P}_{2} \mathrm{O}_{5}$ uptake & $21.3-47.0$ & 40.4 & $22.2-57.6$ & 44.0 & $25.1-60.6$ & 47.5 \\
$\mathrm{~K}_{2} \mathrm{O}$ uptake & & & &
\end{tabular}

Table 3: Values of basic parameters used for developing STCR based fertilizer prescription equations.

\begin{tabular}{lcccccc}
\hline & \multicolumn{3}{c}{ Rice cv.White ponni } & \multicolumn{3}{c}{ Rice cv. ADT 45 } \\
\cline { 2 - 6 } Parameter & $\mathbf{N}$ & $\mathbf{P}_{2} \mathbf{O}_{5}$ & $\mathbf{K}_{\mathbf{2}} \mathbf{O}$ & $\mathbf{N}$ & $\mathbf{P}_{\mathbf{2}} \mathbf{O}_{\mathbf{5}}$ & $\mathbf{K}_{\mathbf{2}} \mathbf{O}$ \\
\hline Nutrient requirement $\left(\mathrm{kg} \mathrm{q}^{-1}\right)$ & 1.44 & 0.58 & 1.37 & 1.25 & 0.73 & 1.01 \\
Per cent contribution from soil (CS) & 19.15 & 12.13 & 13.76 & 13.48 & 15.81 & 10.48 \\
Per cent contribution from fertilizer (CF) & 45.90 & 40.16 & 79.74 & 40.46 & 44.64 & 58.60 \\
Per cent contribution from FYM (CFYM) & 23.27 & 26.98 & 41.07 & 34.26 & 19.89 & 41.51 \\
\hline
\end{tabular}

Table 4: Soil test based fertilizer prescription equations for targeted yield of rice-rice sequence.

\begin{tabular}{lll}
\hline Particular & Rice cv.White ponni & Rice cv. ADT 45 \\
\hline Fertilizer alone & & \\
FN $($ Fertilizer N-kg ha-1) & $3.13 \mathrm{~T}-0.42 \mathrm{SN}$ & $3.13 \mathrm{~T}-0.42 \mathrm{SN}-0.51 \mathrm{ON}$ \\
$\mathrm{F} \mathrm{P}_{2} \mathrm{O}_{5}\left(\right.$ Fertilizer $\left.\mathrm{P}_{2} 0_{5}-\mathrm{kg} \mathrm{ha}^{-1}\right)$ & $1.45 \mathrm{~T}-0.69 \mathrm{SP}$ & $1.45 \mathrm{~T}-0.69 \mathrm{SP}-1.54 \mathrm{OP}$ \\
$\mathrm{F} \mathrm{K}_{2} 0\left(\right.$ Fertilizer $\left.\mathrm{K}_{2} 0-\mathrm{kg} \mathrm{ha}^{-1}\right)$ & $1.72 \mathrm{~T}-0.21 \mathrm{SK}$ & $1.72 \mathrm{~T}-0.21 \mathrm{SK}-0.62 \mathrm{OK}$ \\
Fertilizer with FYM & & \\
FN $($ Fertilizer N-kg ha & & $3.06 \mathrm{~T}-0.33 \mathrm{SN}-0.85 \mathrm{ON}$ \\
$\mathrm{F} \mathrm{P}_{2} \mathrm{O}_{5}\left(\right.$ Fertilizer $\left.\mathrm{P}_{2} 0_{5}-\mathrm{kg} \mathrm{ha}^{-1}\right)$ & $3.06 \mathrm{~T}-0.33 \mathrm{SN}$ & $1.63 \mathrm{~T}-0.81 \mathrm{SP}-1.02 \mathrm{OP}$ \\
$\mathrm{F} \mathrm{K}_{2} 0\left(\right.$ Fertilizer $\left.\mathrm{K}_{2} 0-\mathrm{kg} \mathrm{ha}^{-1}\right)$ & $1.63 \mathrm{~T}-0.81 \mathrm{SP}$ & $1.70 \mathrm{~T}-0.22 \mathrm{SK}-0.85 \mathrm{OK}$ \\
\hline
\end{tabular}

T-yield target in $\mathrm{q} \mathrm{ha}^{-1}$; SN,SP and SK-soil available N,P and K ;ON,OP and OK-N,P and K applied through FYM.

Grain yield and nutrient uptake: Range and mean values of grain yield and nutrient uptake under different strips are presented in Table 2. Maximum yield both rice crops was obtained in strip III followed by strip II and I. It is stated that a crop which is grown under favourable environment is bound to produce better yields, provided the nutrient supply is matching with nutrient accumulation that occurs in the crop. The strip -wise average nutrient uptake was in the order III $>$ II $>$ I for both the crops. The result indicated that a wide variability existed in the soil test values, grain yield and nutrient uptake which is a pre-requisite for calculating the basic parameters and fertilizer prescription equations for calibrating the fertilizer doses for specific yield targets (Santhi et al., 2002)

Basic Parameters for Fertilizer Prescription Equations: The basic parameters for developing fertilizer prescription equation for rice-rice sequence viz. i) nutrient requirement in $\mathrm{kg} \mathrm{q}^{-1}$ of rice (NR), ii) per cent contribution from soil available nutrient (Cs), iii) per cent contribution from fertilizer (CF) and iv) per cent contribution from FYM (CFYM). The nutrient requirement for the production of one quintal of rice cv White ponni and cv ADT 45 were computed as $1.44,0.58$ and 1.37 and $1.25,0.73$ and $1.01 \mathrm{~kg}$ of $\mathrm{N}, \mathrm{P}_{2} \mathrm{O}_{5}$ and $\mathrm{K}_{2} \mathrm{O}$, respectively (Table 3 ). The per cent contribution from soil for rice cv White ponni and cv ADT 45 was found to be 19.15 and 13.48 for $\mathrm{N}, 12.13$ and 15.81 for $\mathrm{P}_{2} \mathrm{O}_{5}$ and 13.76 and 10.48 for $\mathrm{K}_{2} \mathrm{O}$, respectively. The per cent contribution of nutrients from the fertilizer sources revealed that among the three nutrients contribution was more in the case of $\mathrm{K}$ compared to $\mathrm{N}$ and $\mathrm{P}$. The higher value of $\mathrm{K}$ could be due to interaction effect of higher doses of $\mathrm{N}$ and $\mathrm{P}$ coupled with priming effect of $\mathrm{K}$ doses, which might have caused the release of soil $\mathrm{K}$, resulting in the higher uptake in the native soil sources by the crop ( Ray et al., 2000). 
Table 5: Fertilizer recommendation $\left(\mathrm{kg} \mathrm{ha}^{-1}\right)$ for targetted yield rice- rice sequence under NPK and NPK+FYM.

\begin{tabular}{|c|c|c|c|c|}
\hline \multirow{2}{*}{$\begin{array}{l}\text { Soil test values } \\
\mathrm{N}: \mathbf{P}_{2} \mathrm{O}_{5}: \mathrm{K}_{2} \mathrm{O}-\left(\mathrm{kg} \mathrm{ha}^{-1}\right) \\
\text { Rice cv. White ponni }\end{array}$} & \multicolumn{2}{|c|}{ NPK alone } & \multicolumn{2}{|c|}{$\begin{array}{r}\text { NPK + FYM } \\
\left(12.5 \text { t ha }^{-1}\right)\end{array}$} \\
\hline & & & & \\
\hline & $60 \mathrm{q} \mathrm{ha}^{-1}$ & 70 q ha $^{-1}$ & $60 q h^{-1}$ & $70 \mathbf{q ~ h a}^{-1}$ \\
\hline 200: $12: 120$ & $104: 79: 78$ & 136: $93: 95$ & 58: 50: 44 & 89: 64: 61 \\
\hline 240: 16: 160 & $88: 76: 70$ & 119: 91:87 & $41: 47: 36$ & $72: 62: 53$ \\
\hline 280: 20: 200 & $71: 73: 62$ & 102: $88: 79$ & $38: 44: 27$ & 56: $59: 45$ \\
\hline \multicolumn{5}{|l|}{ Rice cv. ADT 45} \\
\hline & $60 \mathrm{q} \mathrm{ha}^{-1}$ & 70 q ha $^{-1}$ & $60 q h^{-1}$ & 70 q ha $^{-1}$ \\
\hline 200: $12: 120$ & 118: $88: 76$ & 149: $104: 93$ & $75: 59: 30$ & $99: 75: 47$ \\
\hline 240: $16: 160$ & 105: 84: 68 & 136: $101: 85$ & $75: 56: 25$ & $85: 72: 39$ \\
\hline 280: 20: 200 & 92: 81: 59 & 122: $97: 76$ & $75: 52: 25$ & $75: 69: 30$ \\
\hline
\end{tabular}

The per cent contribution of $\mathrm{N}, \mathrm{P}_{2} \mathrm{O}_{5}$ and $\mathrm{K}_{2} \mathrm{O}$ from FYM was 23.27, 26.98 and 41.07, respectively for rice cv.White ponni and $34.26,19.89$ and 41.51 for rice cv.ADT 45 (Table 3). In both the cases higher contribution was recorded in the case of $\mathrm{K}$, which might be due to the good supply of carbon which act as the source of energy for the buildup of bacterial population which inturn would have enhanced the release of $\mathrm{K}$ from organic and native sources. The findings are in close conformity with those of Natesan et al. (2007).

Fertilizer Prescription equations for desired yield targets: Based on the basic parameters, fertilizer prescription equations for targeted yield of both rice varieties under NPK alone as well as NPK + FYM were formulated and are furnished in Table 4. On the basis of these equations, a ready reckoner was prepared for making fertilizer recommendations for different soil test values to meet specified yield targets of rice under NPK alone and NPK + FYM (Table 5).

Based on the fertilizer prescription equations for rice cv White ponni for NPK alone, fertilizer $\mathrm{N}$ recommendation was found in the range from $102-136$, fertilizer $\mathrm{P}_{2} \mathrm{O}_{5}$ from 88 - 93 and fertilizer $\mathrm{K}_{2} \mathrm{O}$ from 79 - 95 $\mathrm{kg} \mathrm{ha}^{-1}$ for attaining a yield target of $70 \mathrm{q} \mathrm{ha}^{-1}$ (Table 5). When FYM was applied along with NPK fertilizers, fertilizer requirement of $\mathrm{N}, \mathrm{P}_{2} \mathrm{O}_{5}$ and $\mathrm{K}_{2} \mathrm{O}$ was found in the range of 56 to 89,59 to 64 and $45 \mathrm{~kg} \mathrm{ha}^{-1}$, respectively at the same level of soil test values. Similar trend also observed in rice cv.ADT 45. Under NPK + FYM @ 12.5 t ha $^{-1}$, 47, 29, 34 and 41, 22 and $27 \mathrm{~kg} \mathrm{ha}^{-1}$ of fertilizer $\mathrm{N}, \mathrm{P}_{2} \mathrm{O}_{5}$ and $\mathrm{K}_{2} \mathrm{O}$, respectively could be saved for attaining target yield of $70 \mathrm{q}$ $\mathrm{ha}^{-1}$ for rice cv. White ponni and cv.ADT 45 as compared to NPK fertilizers alone. Similar results were also reported by Anjali Basumatary et al. (2015). Use of FYM resulted in saving of fertilizer nutrients in rice-rice cropping sequence. Practice of fertilizing rice crop using fertilizer prescription equations developed would help in achieving higher productivity, nutrient use efficiency and profitability.

\section{ACKNOWLEDGMENT}

The financial assistance of AICRIP-STCR, Bhopal to carry out the research is gratefully acknowledged.

\section{REFERENCES}

Ajaykumar. R., Venkitaswamy R. and Rajeshkumar A. (2016). Sustainable nutrient management practices to increase the productivity of transplanted low land rice. Cleanup India, TNAU, Coimbatore.

Anjali Basumatary., Ahmed, S and Das, K.N (2015). Soil test based fertilizer prescriptions under integrated plant nutrient supply for rice-rice cropping sequence in Inceptisol of Assam. Journal of Indian Society of Soil Science. 63: 186-190.

Bagavathi Ammal, U., Sankar, R., Coumaravel, K and Baskar. A. (2013). Studies on minimizing N fertilizer through STCR-IPNS. In: Proc. International conference on "Conventional or Non-conventional Organic Inputs in Agriculture" Pondicherry, $209-210$.

Coumaravel, K. (2012). Soil Test Crop Response correlation studies through integrated plant nutrition system for maize-tomato sequence. Ph.D. (Ag.) Thesis, TNAU, Coimbatore.

Dey, P. (2016). Soil Health Management. Bulletin of Indian Society of Soil Science. 13:79-97.

Humphrie E.C. (1956). Mineral components and ash analysis. Modern Method of Plant Analysis: 468-502.

ICAR and NAAS (2010). Degraded and Wastelands of India, Status and Spatial Distribution, Indian Council of Agricultural Research and National Academy of Agricultural Sciences, New Delhi: 158.

Jackson, M.L. (1973). Soil Chemical Analysis. New Delhi.

Karsangla, A.O. and Gohain.T. (2015). Effect of different doses of NPK fertilizers on local rice (Oryza sativa L.) under direct-seeded upland condition. Journal of Soils and Crops 25: 54-61.

Natesan, R., Murugesa Boopathi, P., Santhi, R., Thiyageswari, S., Chandra Sekaran, N., Paulraj, C., Natarajan, S., Subba Rao, A and Muralidharudu. Y. (2007). Bull. Soil Test Crop Response Based Fertilizer Prescription for Different Soils and Crops. 
Olsen, S.R., Cole, C.V., Watanabe, F.S and Dean. L.A. (1954).Estimation of available phosphorus in soil by extraction with sodium carbonate.USDA, CIRC: 939.

Prasad, J. (2004). Environmental implications of soil degradation in India - A review. Agricultural Reviews. 25:57-63.

Ramamoorthy, B., Narasimham, R.K. and Dinesh. R.S (1967). Fertilizer application for specific yield taregts on Sonora 64 (wheat). Indian Farming. 17: 43-45.

Ramamoorthy, B and Velayutham.. M. (2011). The Law of Optimum and soil test base fertilizer use for targeted yield of crops and soil fertility management for sustainable agriculture. Madras Agricultural Journal. 98: 295-307.

Ray, P., Jana, K., Maitra, A.K., Saha, D.N., Chaudhury, M.N., J.S. Saha, J.S. and Saha. A.R. (2000). Fertilizer prescription on soil test basis for jute, rice and wheat in a Typic Ustochrept. Journal of Indian Society of Soil Science. 48: 79-84.

Santhi, R., Natesan. R. and Selvakumari.G. (2002). Soil test based fertilizer recommendation under IPNS for aggregatum onion in Inceptisol of Tamil Nadu. Agropedology. 12: 141-147.

Stanford, S. and English L. (1949). Use of flame photometer on rapid soil tests of K. Canadian J. Agronomy. 41: 446-447.

Subbiah, S.V. and Asija, C.L. (1956). Arapid procedure for the estimation of available nitrogen in soil. Curr.Sci. 25: 259-260.

Tandon, HLS. (2014). Soil testing for balanced fertilization. FDCO, New Delhi: 170.

Tiwari, R.K., Jha, A., Tripathi, S.K., Khan, I.M. and Rao. S.K (2013). Rice based cropping system and climate change. JNKVV. Research Journal. 47:239-247.

Velayutham, M., Santhi, R., Subba Rao, A., Muralidharudu, Y. and Dey.P.(2016). The Law of Optimum and its application for realizing targeted yields in India- A mini review (Thaninayagam Adigal):12-20. 